\title{
Endoscopic submucosal dissection of early duodenal tumor using the Clutch Cutter: a preliminary clinical study
}

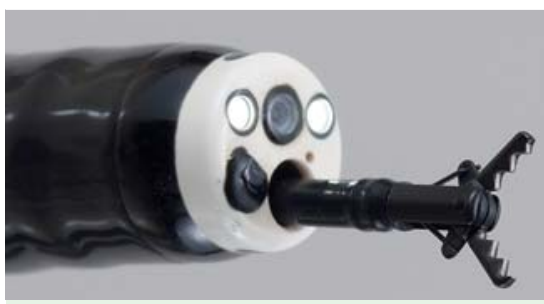

Fig. 1 Photograph showing the short-type Clutch Cutter.

Endoscopic submucosal dissection (ESD) is a minimally invasive method of treating early-stage tumors of the digestive tract. However, duodenal ESD is technically difficult, with high complication rates resulting from poor control of the endoscope, the thin duodenal wall, and the potential for exposure to pancreatic juices [1-2]. This study evaluated the safety of ESD using the short-type Clutch Cutter for the removal of early duodenal tumors.

The short-type Clutch Cutter (DP2618DT; Fujifilm Corporation, Tokyo, Japan) ( $\bullet$ Fig. 1) has previously been described in detail [3]. When the Clutch Cutter is being used for ESD of duodenal tumors, electrical damage to the thin muscle layer can be prevented by grasping the tissue and lifting it from the underlying proper muscle layer, before cutting or coagulating it. The steps of the ESD technique using the Clutch Cutter are illustrated in - Fig. 2.

Between September 2009 and December 2014 , seven patients endoscopically diagnosed with early duodenal tumors underwent ESD using the Clutch Cutter ( Table 1; $\bullet$ Fig.3). Preliminary esophagogastroduodenoscopy (EGD), endoscopic ultrasound (EUS), and endoscopic biopsy showed no evidence of lymph node metastasis in any of the patients. Almost all post-ESD ulcers were closed with clips to prevent delayed perforation. After ESD, all patients were treated with intravenous fluids and antibiotics for at least 2 days, and with an acid-suppression agent (rabeprazole $10 \mathrm{mg} /$ day) for a minimum of 6 weeks.

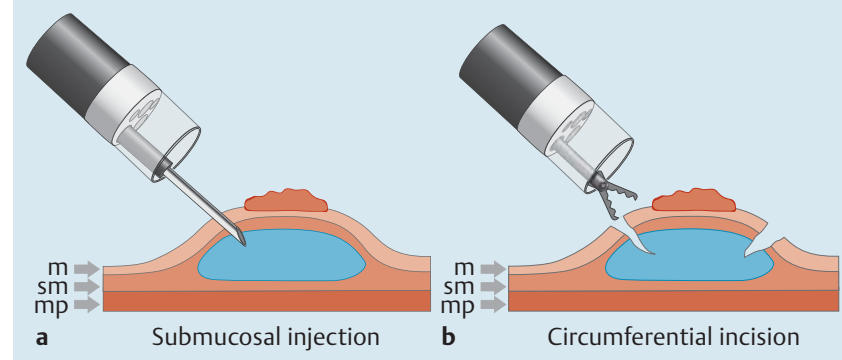

Fig. 2 Schematic of the endoscopic submucosal dissection (ESD) technique using the short-type Clutch Cutter. a A solution of sodium hyaluronate containing epinephrine and indigo carmine dye is injected into the submucosal layer around the target lesion to lift the entire lesion.

b The lesion is separated from the surrounding normal mucosa by a complete circumferential incision around the lesion using the short-type Clutch Cutter. c A piece of submucosal tissue is grasped, lifted, and cut with the short-type Clutch Cutter using electrosurgical current to effect submucosal excision. $\mathbf{d}$ The lesion is resected in one piece. e The post-ESD ulcer is closed using endoscopic clips. m, mucosa; sm, submucosa; mp, muscularis propria.

Clinical outcomes are summarized in - Table 1. All lesions were resected easily and safely in one piece. There were no complications. Follow-up EGD at a mean of 8.7 months showed no incidence of tumor recurrence. Although endoscopically normal tissue had been excised in all patients, the margins could not be assessed pathologically in some of the patients, most likely as a result of heat denaturation.

Although we assessed only a few patients, this study showed that ESD using the Clutch Cutter was safe for duodenal tumors.

Endoscopy_UCTN_Code_TTT_1AO_2AG
Competing interests: Kazuya Akahoshi and Hidefumi Akahane (Fujifilm) have applied for a European patent for the Clutch Cutter described in this article. This patent has been granted in Japan, China, and the USA.

\section{Yosuke Minoda ${ }^{1}$, Kazuya Akahoshi' ${ }^{1}$, Yoshihiro Otsuka', Masaru Kubokawa', Yasuaki Motomura', Masafumi Oya², Kazuhiko Nakamura ${ }^{3}$}

${ }^{1}$ Department of Gastroenterology, Aso lizuka Hospital, lizuka, Japan

2 Department of Pathology, Aso lizuka Hospital, lizuka, Japan

${ }^{3}$ Department of Medicine and Bioregulatory Science, Graduate School of Medical Sciences, Kyushu University, Fukuoka, Japan 

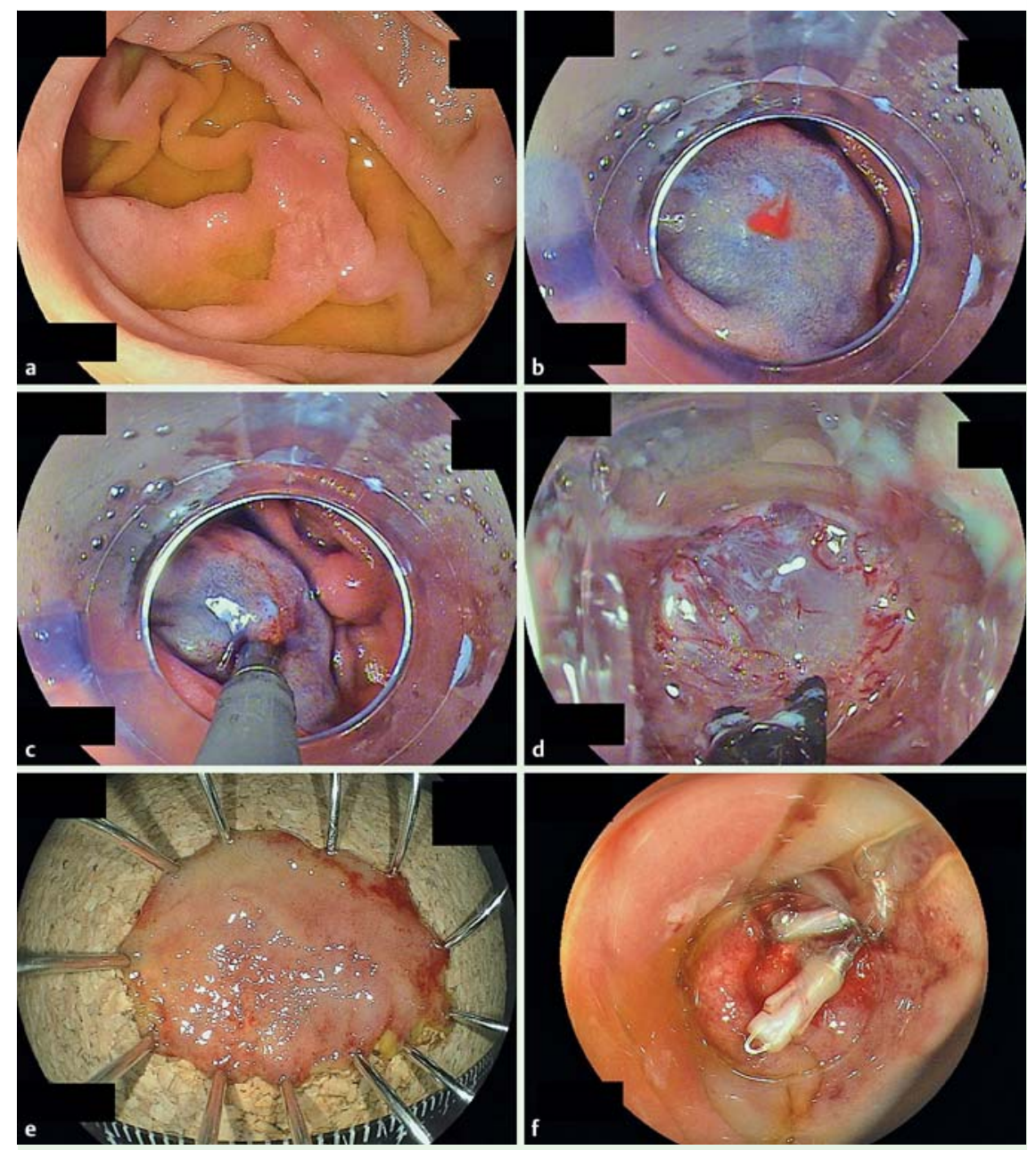

\section{References}

1 Honda T, Yamamoto H, Osawa H et al. Endoscopic submucosal dissection for superficial duodenal neoplasms. Dig Endosc 2009; 21: 270-274

2 Takahashi T, Ando T, Kabeshima $Y$ et al. Borderline cases between benignancy and malignancy of the duodenum diagnosed successfully by endoscopic submucosal dissection. Scand J Gastrenterol 2009; 44: 1377-1383

3 Akahoshi K, Akahane H, Motomura Y et al. A new approach: endoscopic submucosal dissection using the Clutch Cutter for early stage digestive tract tumors. Digestion 2012; 85: 80-84

\section{Bibliography}

DOI http://dx.doi.org/

10.1055/s-0034-1392209

Endoscopy 2015; 47: E267-E268

(c) Georg Thieme Verlag KG

Stuttgart · New York

ISSN 0013-726X

\section{Corresponding author}

\section{Kazuya Akahoshi, MD, PhD}

Department of Gastroenterology

Aso lizuka Hospital

3-83 Yoshio

lizuka 820-8505

Japan

Fax: +81-948-298747

kakahoshi2@aol.com

Fig. 3 Endoscopic submucosal dissection (ESD) using the short-type Clutch Cutter: a a lesion located in the duodenum; $\mathbf{b}$ a solution of sodium hyaluronate being injected into the submucosal layer; $\mathbf{c}$ the non-neoplastic mucosa being grasped and incised; $\mathbf{d}$ the submucosal tissue being grasped, lifted, and excised from the muscle layer; $\mathbf{e}$ the resected specimen following its removal; $\mathbf{f}$ the post-ESD ulcer which has been closed with endoscopic clips.

Table 1 Baseline, lesion, and procedural characteristics for the seven patients who underwent endoscopic submucosal dissection (ESD) of early duodenal tumors using the Clutch Cutter.

\begin{tabular}{|c|c|c|c|c|c|c|c|c|c|c|}
\hline $\begin{array}{l}\text { Patient } \\
\text { number }\end{array}$ & $\begin{array}{l}\text { Age, } \\
\text { Sex }\end{array}$ & $\begin{array}{l}\text { Tumor } \\
\text { Location } \\
\text { within } \\
\text { duodenum }\end{array}$ & Type & $\begin{array}{l}\text { Diameter, } \\
\mathrm{mm}\end{array}$ & $\begin{array}{l}\text { Operating } \\
\text { time, } \\
\text { minutes }\end{array}$ & $\begin{array}{l}\text { Resected } \\
\text { specimen } \\
\text { diameter, } \\
\text { mm }\end{array}$ & $\begin{array}{l}\text { Resection } \\
\text { margin } \\
\text { lateral/ } \\
\text { vertical }\end{array}$ & $\begin{array}{l}\text { En bloc } \\
\text { resection }\end{array}$ & Histology & Complications \\
\hline 1 & $\begin{array}{l}31, \\
\text { Female }\end{array}$ & Bulb & Ila & 11 & 172 & 23 & $\mathrm{X} /-$ & Yes & Adenoma & None \\
\hline 2 & $\begin{array}{l}56, \\
\text { Male }\end{array}$ & 3rd portion & $1+11 \mathrm{a}$ & 20 & 55 & 30 & $\mathrm{X} /-$ & Yes & Adenocarcinoma & None \\
\hline 3 & $\begin{array}{l}78, \\
\text { Female }\end{array}$ & 2nd portion & I & 45 & 62 & 50 & $\mathrm{X} /-$ & Yes & Adenocarcinoma & None \\
\hline 4 & $\begin{array}{l}\text { 56, } \\
\text { Male }\end{array}$ & 2nd portion & IIc & 15 & 55 & 22 & $-1-$ & Yes & Adenocarcinoma & None \\
\hline 5 & $\begin{array}{l}73, \\
\text { Female }\end{array}$ & 2nd portion & Ila & 20 & 78 & 28 & $-1-$ & Yes & Adenoma & None \\
\hline 6 & $\begin{array}{l}62, \\
\text { Female }\end{array}$ & 2nd portion & Ila & 13 & 137 & 25 & $x / X$ & Yes & Adenoma & None \\
\hline 7 & $\begin{array}{l}68, \\
\text { Female }\end{array}$ & 2nd portion & Ila & 17 & 107 & 20 & $\mathrm{X} /-$ & Yes & Adenocarcinoma & None \\
\hline
\end{tabular}

$X$, margin could not be assessed; -, margin clear. 